\title{
FENOMENA REMAJA PUNK DITINJAU DARI KONSEP PERSON IN ENVIRONMENT (STUDI DESKRIPTIF DI KOMUNITAS HEAVEN HOLIC KOTA BANDUNG)
}

\author{
Oleh: \\ Anna Rizky Annisa, Budhi Wibhawa, dan Nurliana Cipta Apsari \\ E-mail : \\ (narizan94@gmail.com; budhiwibhawa@gmail.com; nurliana.apsari@gmail.com)
}

\begin{abstract}
Abstrak
Remaja punk merupakan bagian dari kehidupan underground. Mereka memiliki ideologi politik dan sosial, hidup di jalanan dan selalu mendengarkan musik-musik yang beraliran keras. Mereka hadir di jalan untuk melakukan perlawanan terhadap kondisi sosial, politik dan budaya di masyarakat. Keberadaan remaja punk di berbagai sudut Kota Bandung telah meresahkan sebagian masyarakat. Penampilan mereka yang ekstrim dengan memakai sepatu boots, jaket kulit, celana jeans yang robek, menggunakan gelang berduri, memakai baju hitam lusuh dan memiliki rambut mohawk seperti suku indian dengan warna yang mencolok telah membuat risih sebagian masyarakat. Mereka sangat berani untuk berbeda dari orang lain dan menciptakan suatu tren tersendiri. Remaja punk terbentuk karena tinggal dengan lingkungan serupa. Dalam konsep Ilmu Kesejahteraan Sosial, terdapat sebuah konsep yaitu Person In Environment yang merupakan holistic model system untuk mengidentifikasi serta mengklarifikasi permasalahan-permasalahan klien atau pasien dalam keberfungsian sosial. Melalui penelitian ini akan dideskripsikan Person Dimensional remaja punk berupa kondisi biologis, kondisi psikologis dan spiritual yang mereka miliki. Kemudian melihat environmental dimensional remaja punk berupa lingkungan fisik di sekitar mereka dan budaya yang mereka anut. Selanjutnya adalah Time Dimensional berupa rencana dan kejadian-kejadian yang dialami oleh remaja punk.
\end{abstract}

\section{Abstract}

Punks is part of the underground. lifeThey have the ideology of the political and social life on the streets and always hear and listen to mellow that fencing hard.Them is here in a way to do resistance to the social condition, political and cultural in society. The existence of punks at different corners of the city of bandung has been unsettling some parts of the community. Their appearance to the extreme by wearing boots, black leather jacket, blue jeans being torn, using a bracelet prickly, wear a black shabby and having hair mohawk as a tribe of indians with striking color have made some in the community be uncomfortable. They are very brave to be different from others and create of trends in and of itself. Punks formed for staying with the environment similar. In the concept of the science of social welfare, there is a concept which is holistic person in environment which is a model system to identify and clarify the problems in social function client or patient . Through this research will be described person dimensional punks of biological condition, psychological and spiritual condition that they have. Then see the environmental dimensional punks of the physical environment around them and their cultural .Dimensional next time is of the plan and events experienced by punks .Keyword : Remaja, Punk, Person In Enveronment, Pekerjaan Sosial, Masalah Sosial 


\section{Pendahuluan}

Punk merupakan suatu ideologi tentang pemberontakan dan anti kemapanan, dengan berbagai macam karakter dari tiap anggota sehingga sebuah kelompok untuk mendapatkan keamanan identitas diri dan ciri dari komunitas punk tersebut. Menurut Counter Culture "Punk yang sesungguhnya adalah sebuah pergerakan revolusioner antipenindasan dan sebuah gerakan libertarian(kemerdekaan) dari kelompok orang-orangyang tidakpuas terhadap kondisi yang terjadi saat ini".

Punk berasal dari bahasa Inggris, yang merupakan singkatan dari "Public United Not Kingdom" yang artinya adalah kesatuan masyarakat di luar kerajaan. (Firmansah, 2013) Dalam perkembangannya, punk memiliki berbagai jenis dengan ciri khas yang cukup berbeda satu sama lain.

Punk masuk Indonesia pada akhir delapan puluhan, tetapi perkembangan besar terjadi pada awal pertengahan tahun sembilan puluhan. Pickles (2000) mengatakan bahwa pada waktu itu estetis dan musik punk menjadi cara hidup altematif yang baru dan populer bagi pemuda Indonesia. pada awalnya punk di Indonesia, budaya ini tidak melebih mode dan musik. Pada waktu itu punk mempakan sebuah subkultur yang dinamis dan eksperimental dengan pesan-pesan pemberontakan visual tapi tidak bisa dianggap sebuah budaya perlawanan yang bersatu dan bekerjasama supaya tujuan tercapai.

Punk adalah suatu ideologi tentang pemberontakan dan anti kemapanan, dengan berbagai macam karakter dari tiap anggota sehingga membentuk sebuah kelompok untuk mendapatkan keamanan identitas diri dan ciri dari komunitas punk tersebut.

O'hara (1999) mengartikan punk sebagai suatu bentuk tren remaja dalam berpakaian dan bermusik, suatu keberanian dalam membuat perubahan, dan suatu bentuk perlawanan yang luar biasa karena menciptakan musik, gaya hidup, komunitas dan kebudayaan sendiri.

Remaja punk begitu percaya diri akan penampilannya yang berbeda dengan orang pada umumnya. Marshal (2005) berpendapat bahwa generasi muda. yang bergabung dalam komunitas punk merasa menemukan jati diri mereka terhadap gaya unik yang ditonjolkan oleh punk. Komunitas punk di Indonesia sangat diwarnai oleh budaya dari barat atau Amerika dan Eropa. Biasanya perilaku mereka terlihat dari gaya busana yang mereka kenakan seperti sepatu boots, potongan rambut mohawk ala suku Indian, atau dipotong ala feathercut dan diwarnai dengan warna-warna yang terang, rantai dan spike, jaket kulit, celana jeans ketat dan baju yang lusuh, anti kemapanan, anti sosial, kaum perusuh dan kriminal dari kelas rendah, pemabuk berbahaya sehingga banyak yang mengira bahwa orang yang berpenampilan seperti itu sudah layak untuk disebut dengan punker.

Menurut Nando (2008:5) bahwa "Punkers sering dianggap sebagai tukang kritik melalui lirik-liriknya, dan tukang "rusuh" melalui aksi egalitarian dari para penganutnya meskipun itu belum tentu benar."

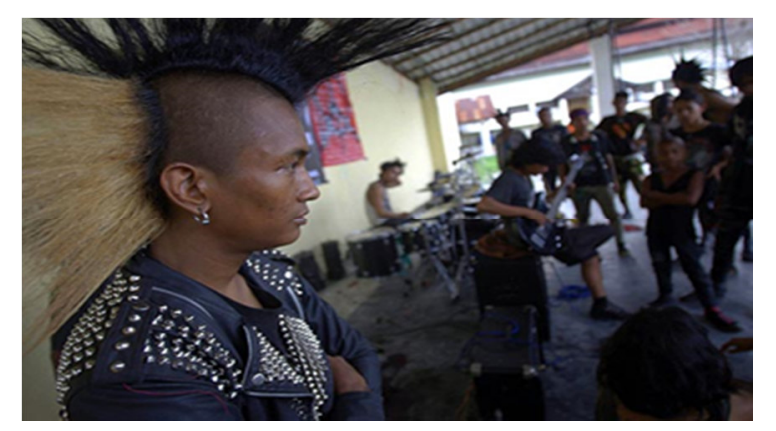




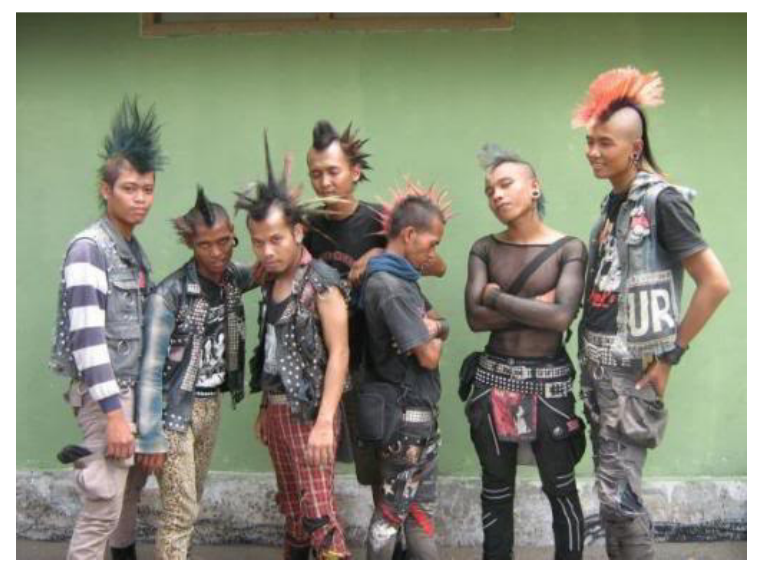

Ciri khas komunitas punk lainnya adalah aliran musik yang mereka miliki. Musik punk merupakan musik pemberontakan, pemberontakan dilakukan melalui lirik lagu yang menyindir perilaku pemerintah yang tidak peduli terhadap masyarakat. Firmansah (2013) berpendapat bahwa Punk sering dikatakan sebagai salah satu seni yang terangkum dalam berbagai macam seni, misalnya musik. Lirik dalam musik ini juga sebagai alat untuk memprovokasi serta melakukan perlawanan. Tetapi, pada umumnya masyarakat menilai musik punk sebagai musik yang negatif dan menganggu tatanan sosial.

Punk merupakan budaya tersendiri di Masyarakat, karena mereka telah menciptakan struktur sosial tersendiri. Piliang (1998: 213) berpendapat bahwa budaya punk sebagai budaya subkultur, muncul dan booming di Indonesia sekitar tahun 90-an atau sekitar tahun 1980-an (Piliang, 1998: 213).

Pengaruh punk di Indonesia bermula dari proses modernisasi dan globalisasi di dunia. Ronaldo (2008) mengatakan bahwa dampak dari modernisasi dan pembangunan adalah terjadinya perubahan atau pembaharuan struktur sosial yang mendorong terjadinya proses transformasi sosial dan budaya dalam tatanan masyarakat Indonesia. Perubahan pola hidup masyarakat dan perubahan budaya yang ada membuat manusia dihadapkan pada stimulasi yang kompleks dan memerlukan kejelian untuk menerima situasi tersebut. Salah satu budaya yang muncul saat ini adalah punk.

Sekelompok orang yang memiliki perilaku dan kepercayaan yang berbeda dengan kebudayaan induk mereka disebut subkultur. Budayawan Fitrah Hamdani dalam Zaelani Tammaka (2007:164) berpendapat bahwa subkultur adalah gejala budaya dalam masyarakat industri dan kemunculannya tidak semata-mata merupakan penentangan terhadap hegemoni bahkan mungkin merupakan salah satu jalan keluar bagi satu ketegangan sosial. Masyarakat subkultur pun telah membentuk budaya dan tradisi mereka sendiri. Hidbige (1988: 158) mengatakan pendukung subkultur menghormati adat atau aturan yang berlaku dan menjadikan aturan itu sebagai pedoman dan acuan bagi hidup mereka.

Perkembangan jumlah remaja punk di Indonesia tidak diketahui secara pasti, namun sebuah fanzine asal Amerika Profane Existence, menulis negara dengan perkembangan punk yang menempati peringkat teratas di dunia adalah Indonesia dan Bulgaria.

Komunitas punk adalah remaja yang hidup di jalanan namun berbeda dengan anak jalanan pada umumnya. Perbedaan terlihat dari cara berpakaian dan juga cara bergaul satu sama lain. Namun dalam pendataan, mereka tergolong kepada anak jalanan. Dari sekian kota/kabupaten di Jabar, jumlah anak jalanan yang ada di Kota Bandung menjadi yang tertinggi mencapai 2.500 orang atau $44 \%$ permasalahan anak jalanan ada di ibu kota provinsi Jabar tersebut.

(http://bandung.bisnis.com/read/20140209/6 1818/490985/anak-jalanan-di-bandungmenjadi-yang-tertinggi) 

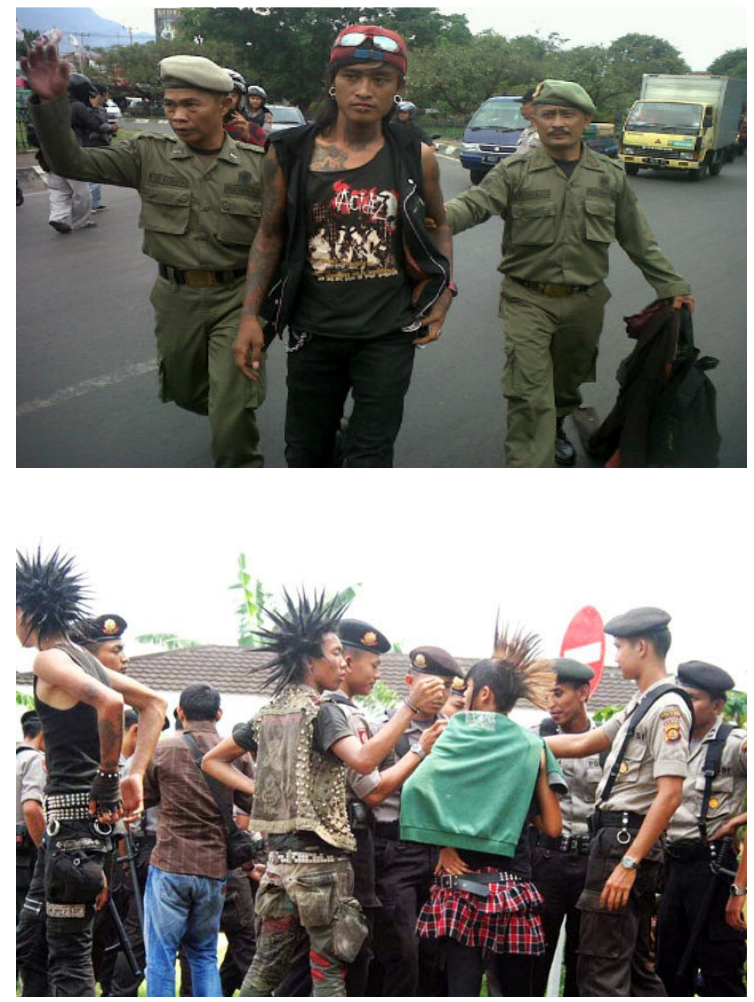

Di Kota Bandung, remaja punk ini memiliki kebiasaan yang membuat masyarakat terganggu saat bepergian menggunakan angkutan umum. Mereka mencari uang dengan cara mengamen di setiap angkutan umum serta menyanyikan lagu-lagu yang berbeda dari pengamen pada umumnya. Perbedaannya terlihat dari liriklirik yang memuat tentang kritikan terhadap pemerintah atau kondisi sosial politik saat ini. Mereka merupakan bagian dari kehidupan underground. Mereka memiliki ideologi politik dan sosial, hidup di jalanan dan selalu mendengarkan musik-musik yang beraliran keras. Mereka hadir di jalan untuk melakukan perlawanan terhadap kondisi sosial, politik dan budaya di masyarakat.

Selain mengamen, remaja punk juga menuliskan pesan politik di tembok kantorkantor di Kota Bandung. Hotibin (2008) mengatakan pesan politik tersebut ada di beberapa kantor yaitu di simpang Jalan Merdeka serta Jalan R.E Martadinata. Pesan tersebut antara lain adalah "Bubarkan Negara", "Pemerintah = Racun" , "Negara = Racun", dan "Keraskan Kepala".
Sangat mudah untuk menemukan komunitas punk di Kota Bandung. Mereka saling berkumpul satu sama lain di tempat yang terbuka. Terdapat beberapa titik komunitas punk di kota ini. Diantaranya di pusat kota yaitu di Jalan Braga, alun-alun Cicalengka dan di pintu tol Pasteur. Beberapa dari komunitas ini tinggal di jalanan dan berprofesi sebagai pengamen. Ada pula yang sudah profesional dan terlibat rekaman (Muthiya, 2008).

Kesan dan stigma negatif telah melekat pada komunitas punk ini. Mereka dianggap sebagai pembuat onar, preman, perusuh, dan banyak orang yang menganggap mereka berbahaya. Sudah banyak upaya razia yang dilakukan oleh Satpol PP untuk mengamankan keberadaan mereka. Namun tetap saja tidak mengurangi jumlah remaja punk yang ada di Kota Bandung.

(http://news.detik.com/read/2013/10/18/155 611/2389488/486/wali-kota-bandung-pimpinrazia-gepeng-remaja-berdandan-punk-kocarkacir)

Komunitas Heaven Holic dibentuk dari keprihatian pada dunia generasi muda saat ini yang tengah menghadapi permasalahan sosial berupa pergaulan bebas yang mempengaruhi pemikiran mereka. Banyak dari generasi muda terutama remaja punk yang terjebak dalam perilaku negatif dan merusak, dari mulai minuman keras, penyalahgunaan narkoba sampai pergaulan bebas termasuk remaja punk.

Komunitas ini dibentuk untuk membina anak, remaja atau dewasa yang pernah bergabung di komunitas punk agar dapat menjalani kehidupan secara normal dengan memberikan pembelajaran baik secara umum maupun secara spiritual guna ikut berkontribusi dalam memperbaiki akhlak dan moral generasi muda termasuk anak punk. 


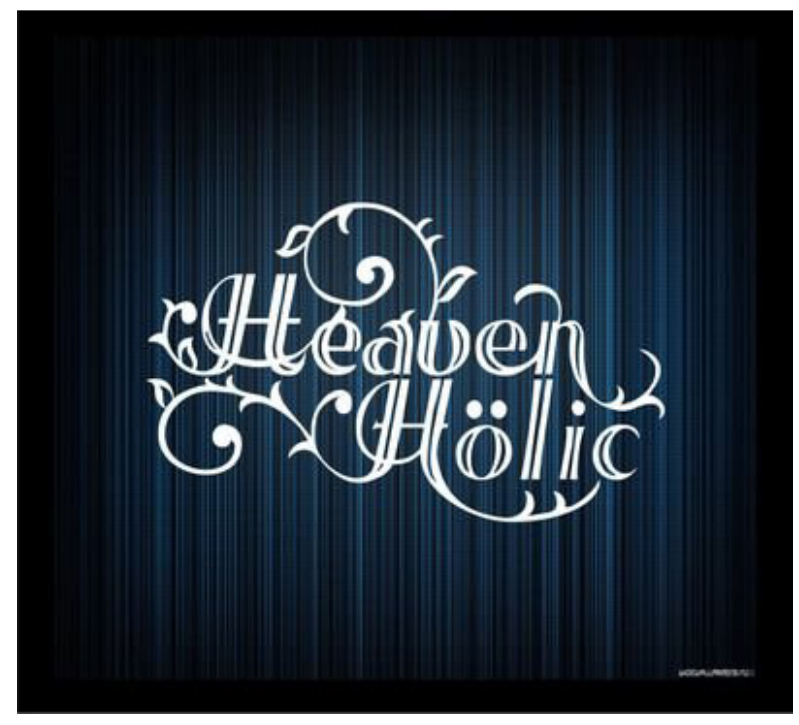

Remaja punk terbentuk karena tinggal dengan lingkungan serupa. Dalam konsep IImu Kesejahteraan Sosial, terdapat sebuah konsep yaitu Person In Environment yang merupakan holistic model system untuk mengidentifikasi serta mengklarifikasi permasalahan-permasalahan klien atau pasien dalam keberfungsian sosial. Melalui penelitian ini akan dideskripsikan Person Dimensional remaja punk berupa kondisi biologis, kondisi psikologis dan spiritual yang mereka miliki. Kemudian melihat environmental dimensional remaja punk berupa lingkungan fisik di sekitar mereka dan budaya yang mereka anut. Selanjutnya adalah Time Dimensiona/ berupa rencana dan kejadian-kejadian yang dialami oleh remaja punk. Untuk mengidentifikasi permasalahan yang menggambarkan permasalahan dalam keberfungsian peran sosial remaja punk berkaitan untuk aktivitas kehidupan keseharian yang dibutuhkan oleh masyarakat atau budaya bagi usia individu dan tahap kehidupan maka perlu penggunaan konsep Person In Environment.

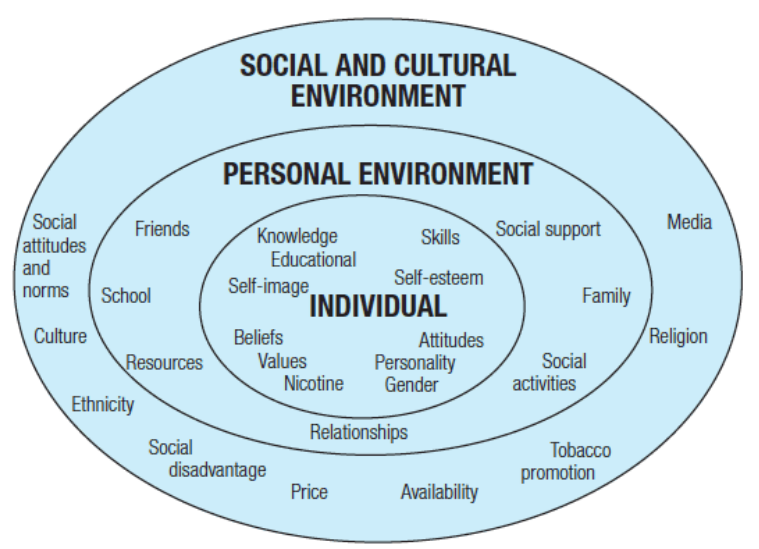

Pendekatan

penelitian

yang digunakan dalam penelitian ini adalah pendekatan kualitatif. Pendekatan kualitatif digunakan karena masalah penelitian belum jelas diketahui, sehingga perlu melakukan eksplorasi terhadap suatu objek dan mengetahui sebuah fenomena secara secara menyeluruh, luas serta mendalam.

Metode penelitian yang digunakan adalah metode deskriptif karena bertujuan untuk memberikan gambaran mengenai fenomena remaja punk ditinjau dari person in environment dengan cara mengeksplorasi secara menyeluruh, luas serta mendalam berdasarkan pada dimensi-dimensi dalam person in environment, diantaranya person dimensional (dimensi manusia), environmental dimensional (dimensi lingkungan), time dimensional (dimensi waktu).

Penelitian ini menggunakan teknik penelitian studi kasus. Dikatakan studi kasus karena peneliti akan melakukan studi secara intensif mengenai keadaan suatu unit konsep dalam pekerjaan sosial, yakni person in environment dari remaja punk binaan komunitas heaven holic.

Setting yang digunakan pada penelitian ini adalah remaja punk dalam naungan binaan komunitas heaven holic. Setting tersebut dipilih dengan maksud dan tujuan untuk melihat serta memberikan gambaran person in environment remaja punk di komunitas heaven holic.Informan adalah 
orang yang secara sukarela menjadi objek dalam penelitian serta orang lain selain objek penelitian yang memahami situasi dan kondisi dari objek penelitian. Informan ditentukan dengan metode purposive, yaitu informan dipilih berdasarkan tujuan tertentu.

Data yang diperoleh langsung peneliti yang berasal dari lokasi penelitian. Data yang termasuk dari data primer yaitu data dari hasil wawancara dan observasi.Dalam metode kualitatif wawancara merupakan metode pengumpulan data yang utama. Definisi wawancara adalah suatu interaksi untuk bertukar informasi. Metode wawancara yang dipakai adalah metode wawancara semi-terstruktur, karena wawancara dengan jenis ini dapat lebih fleksibel dan terkadang pertanyaan dapat muncul ketika sedang berbicara.

Data Sekunder merupakan sumber data penelitian yang diperoleh secara tidak langsung melalui media perantara yang diperoleh dan dicatat pihak lain. Dalam mengumpukan data sekunder, peneliti melakukan studi dokumentasi.

Reduksi data merupakan tahapan ketika informasi yang diperoleh peneliti digabungkan dan diseragamkan menjadi bentuk tulisan. Pada saat mereduksi data maka dikumpulkan data-data yang diperlukan dan membuang informasi yang tidak perlu. Setelah data direduksi maka akan tergambar mengenai hasil dari pengumpulan data.

Data-data yang telah direduksi, digolongkan dalam bentuk matriks atau kategorisasi. Data-data dikelompokkan dalam sebuah tema, kemudian diturunkan dalam subtema. Hal ini dilakukan supaya informasi dapat lebih mudah untuk dimengerti. Kemudian peneliti memasukkan pernyataanpernyataan informan ke dalam matriks kategorisasi dengan kalimat yang dibuat oleh peneliti. Setelah itu akan diberikan kode.
Setelah data selesai disajikan maka akan ditarik kesimpulan. Pada tahap ini pula dilakukan triangulasi data yaitu memeriksa hasil apakah sesuai dengan data yang didapat atau tidak

Penelitian ini dilaksanakan di Komunitas Heaven Holic. Lokasi ini dipilih berdasarkan pertimbangan komunitas ini memiiliki aktivitas yang bertujuan untuk mendidik remaja punk secara spiritual.

Remaja punk terbentuk karena tinggal dengan lingkungan serupa. Dalam konsep Ilmu Kesejahteraan Sosial, terdapat sebuah konsep yaitu Person In Environment yang merupakan holistic model system untuk mengidentifikasi serta mengkla rifikasi permasalahan-permasalahan klien atau pasien dalam keberfungsian sosial.

Menurut Wibhawa (2010:170), Person In Environment (PIE) adalah suatu metode untuk menggambarkan, mengklasifikasi dan mengkoding permasalahan-permasalahan pasien dan klien dewasa yang memperoleh pelayanan pekerja sosial. PIE sistem adalah suatu "holistic model system" yang mengidentifikasi dan mengklasifikasi permasalahan-permasalahan klien atau pasien dalam pengalamannya dengan keberfungsian sosial. Di dalamnya termasuk assessment mengenai hubungan sosial.

Dalam praktik pekerjaan sosial, Person In Environment merupakan sebuah too/ dari assessment terhadap klien. Menurut Hutchison (2003) dalam menggambarkan situasi klien dengan Person In Environment diperlukan pendekatan multidimensional. Pendekatan multidimensional merupakan pemikiran tentang perilaku manusia sebagai perubahan konfigurasi orang dan lingkungan sepanjang waktu. Pendekatan Multidimensional dibangun dengan tiga aspek yaitu Person Dimensional, Environmental Dimensional dan Time Dimensional. 
Fenomena mengenai remaja punk di Kota Bandung penting untuk diteliti karena memberikan gambaran mengenai profil remaja punk binaan komunitas heaven holic ditinjau dari person in environment yang mereka miliki. Karena manusia tidak akan lepas dari pengaruh lingkungannya, begitu pula dengan remaja punk.

Remaja merupakan masa transisi dari masa kanak-kanak menuju masa dewasa, banyak perubahan yang terjadi pada masa remaja yaitu peralihan-peralihan secara fisik, pikiran, lingkungan sosial dan kondisi emosi.

Remaja adalah periode transisi perkembangan antara masa kanak-kanak dengan masa dewasa, yang melibatkan perubahan-perubahan biologis, kognitif, dan sosio-emosional. Tugas pokok remaja adalah mempersiapkan diri memasuki masa dewasa. Sebetulnya masa depan dari seluruh budaya tergantung pada seberapa efektifnya pengasuhan itu (Larson dkk, 2002).

Banyak pendapat mengenai usia batasan remaja, karena remaja merupakan masa transisi, hal ini tergantung dari budaya yang dianut dan sejarah daerah yang dia tempati.

Meskipun rentang usia dan remaja dapat bervariasi terkait dengan lingkungan budaya dan historisnya, masa remaja dimulai sekitar usia 10 hingga 13 tahun dan berakhir pada sekitar usia 18 hingga 22 tahun. Perubahan biologis, kognitif, dan sosioemosional yang dialami remaja dapat berkisar mulai dari perkembangan fungsi seksual hingga proses berpikir abstrak hingga kemandirian. Santrock, 2007)

Perkembangan Remaja

Perkembangan pada saat remaja merupakan titik penting di dalam kehidupan seseorang. Pada masa remaja akan timbul sebuah rangkaian periode perkembangan hidup dipengaruhi oleh interaksi dari prosesproses biologis, kognitif dan sosio-emosional.

Masa kanak-kanak ke remaja, pada masa remaja awal terjadi perubahan di otak yang memungkinkan kemajuan dalam berpikir. Pada masa ini, remaja juga cenderung untuk tetap terjaga hingga larut malam dan bangun tidur agak siang.

Perubahan-perubahan kognitif yang berlangsung selama transisi dari masa kanakkanak hingga remaja adalah meningkatnya berpikir abstrak. Idealistik dan logis. Ketika mereka melalui transisi ini, remaja mulai berpikir secara lebih egosentris, seringkali memandang dirinya seolah-olah berada di atas pentas, unik, dan tak terkalahkan. Sebagai respons terhadap perubahanperubahan ini, orang tua memberikan tanggung jawab lebih besar di pundak remaja untuk membuat keputusan (Santrock, 2007).

Masa remaja terdiri dari masa remaja awal dan masa remaja akhir. Masa remaja awal berlangsung pada saat usia sekolah menengah pertama dan usia sekolah menengah atas. Sementara masa remaja akhir berlangsung pertengahan dasawarsa, pada saat ini remaja memiliki minat karir dan mengeksplorasi identitas diri.

Ada beberapa kecenderungan yang dialami oleh remaja pada masa pubertas, hal ini diakibatkan dari masih labilnya emosi mereka. Adapun diantara kecenderungan yang dialami oleh remaja adalah sebagai berikut :

a. Kecenderungan untuk meniru

b. Kecenderungan untuk mencari perhatian

c. Kecenderungan mulai tertarik pada lawan jenisnya

d. Kecenderungan mencari idola

e. Selalu ingin mencoba terhadap hal-hal yang baru.

f. Emosinya mudah meletup. (Kauma, 1999) 
Ada tiga macam jenis punk, yaitu Punk Hardcore, Street Punk, dan Punk Rock Elite.

\section{Punk Hardcore}

Hardcore punk berkembang pada tahun 1980-an di Amerika Serikat Bagian Utara. Musik dengan aliran punk rock dengan beatbeat yang cepat menjadi musik wajib bagi mereka. Jiwa pemberontakan sangat kental dalam kehidupan sehari-hari, terkadang sesama anggota sering bermasalah. (Marshal, 2005, h.109)

\section{Street Punk}

Street punk adalah punk yang terbiasa tidur di pinggiran jalan dan mengamen untuk membeli rokok. Sering bergaul dengan pengamen dan pengemis. Sebutan street punk adalah The Oi, mereka sering berbuat oner dimana-mana. Para anggotanya diberi nama skinheads. Para skinheads menganut prinsip kerja keras itu wajib. Para skinheads lebih berani mengekspresikan musik dibandingkan komunitas punk lainnya. (Marshal, 2005, h.110)

\section{Punk Rock Elite}

Punk Rock Elite beranggotakan seniman. Mereka menjauhi perselisihan dengan sesama komunitas ataupun orang-orang di sekitarnya. Mereka biasa berkumpul di distro, ataupun kafe. (Marshall, 2005, h.109)

Subkultur merupakan gejala budaya dalam masyarakat industri maju yang umumnya terbentuk berdasarkan usia dan kelas. Secara simbolis diekspresikan dalam bentuk pencipta gaya dan bukan hanya merupakan penentang hegemoni atau jalan keluar suatu ketegangan sosial. Subkultur lebih jauh menjadi bagian dari ruang bagi penganutnya untuk memberikan otonomi dalam suatu tatanan sosial masyarakat industri yang semakin kaku dan kabur. (Audifax dalam Alfahri Addin (2006:122).
Subkultur timbul apabila suatu bagian dari masyarakat atau kelompok sosial tertentu sedang menghadapi masalah yang bukan merupakan persoalan yang dihadapi warga lainnya. (Soekanto, 1990)

\section{Person In Environment}

Dalam praktik pekerjaan sosial terdapat sebuah konsep yaitu konsep Person In Environment, konsep ini akan mengidentifikasi permasalahan yang menggambarkan permasalahan dalam keberfungsian peran sosial berkaitan untuk aktivitas kehidupan keseharian yang dibutuhkan oleh masyarakat atau budaya bagi usia individu dan tahap kehidupan.

Person In Environment dapat secara efektif menilai klien. Seorang praktisi harus akrab dengan Person In Environment dan DSM IV. Kedua hal tersebut akan digunakan sebagai referensi; dengan mengikuti arah tersebut, seseorang bisa menjadi nyaman melakukan penilaian Person In Environment dalam sebulan atau dua bulan.Tentu saja, ada harapan bahwa alat penilaian ini akan mampu bersaing di pasar terbuka dengan medical-model-based dsm-iv. Person In Environment akan mendidik semua pekerjaan sosial praktisi, terutama pekerjaan sosial siswa karena itu adalah cara yang khas profesi kita menilai individu dibandingkan profesi lain.

Person-in-environment adalah konsep dasarnya pekerjaan sosial (Hare, 2004 ). Bahkan ada yang menyatakan bahwa konsep ini, yang menjadi ciri umum pekerjaan sosial sebagai sebuah profesi yang berusaha untuk mengubah dan memperbaiki kehidupan individu dan masyarakat dan hubungan antara mereka, adalah apa yang membedakan dari pekerjaan sosial dengan yang lainnya. (gibelman,1999). Jadi, hal ini tidak mengherankan bahwa banyak sarjana melihat pendekatan person-in-environment 
sebagai pendekatan pusat (Buchbinder, Eisikovits, \& Karnieli-Miller, 2004; Johnson; Kondrat, 2002; Minahan, 1981; Schneider \& Netting, 1999).

Person-in-environment yang diwujudkan dalam konsep dual aspirasi dari profesi untuk memberikan perawatan pribadi dan keadilan sosial yang lebih lanjut. Lebih spesifik lagi, profesi pekerjaan sosial yang bertujuan untuk meningkatkan kemampuan individu, keluarga, kelompok, dan masyarakat untuk menyelesaikan masalah mereka, menyadari potensi mereka, dan meningkatkan kehidupan mereka, sementara mempengaruhi reformasi sosial kemasyarakatan yang dimaksudkan untuk menghilangkan hambatan untuk kesejahteraan individu, untuk mengurangi kesenjangan, dan untuk meningkatkan keadilan sosial (Dominelli, 2004).

Pendekatan person-in-environment yang juga diwujudkan dalam kesepakatan umum yang profesional dalam kelompok pekerja sosial masyarakat yang harus menggunakan intervensi psikologis individu baik pada tingkat tingkat sosial. Tahun 2004 lalu disajikan sebagai suatu pendekatan prinsip pengorganisasian yang menyatukan suatu kesinambungan keberhasilan campur tangan, dimulai dengan psikoterapi atau pekerjaan sosial klinis; melalui terapi keluarga, kelompok kerja, pemberdayaan, penanganan perkara, mediasi, aksi sosial, advokasi, dan kebijakan pembentukan; dan berakhir dengan pembangunan sosial.

Kebutuhan untuk mengintegrasikan kegiatan ini juga menekankan pada tingkat yang berbeda dalam kode etik pekerjaan sosial. Misalnya, british association of social worker' (basw) yang menyatakan bahwa: pekerja sosial mempunyai tanggung jawab untuk membantu individu, keluarga, kelompok, dan masyarakat melalui penyediaan dan operasi dan layanan yang sesuai dengan memberi kontribusi untuk perencanaan sosial dan tindakan (basw, 1996).

Menurut Hutchison (2003) dalam menggambarkan situasi klien dengan Person In Environment diperlukan pendekatan multidimensional. Pendekatan multidimensional merupakan pemikiran tentang perilaku manusia sebagai perubahan konfigurasi orang dan lingkungan sepanjang waktu. Pendekatan Multidimensional dibangun dengan tiga aspek yaitu Person Dimensional, Environmental Dimensional dan Time Dimensional.

\section{Person Dimensional}

a. The Biological Person merupakan gambaran fisik (jenis kelamin, umur, berat badan, tinggi badan, kecacatan (jika ada), penampilan, cara berbicara, ekspresi tubuh, respon awal saat berbicara dengan orang lain, kehangatan, body exspression, dan status kesehatannya.

b. The Psychological Person merupakan gambaran emosi, respon terhadap suatu masalah, pola pikir klien, dan pikiranpikiran dia kepada situasi yang dihadapinya.

c. The Spiritual Person merupakan etika, keyakinan dan kepercayaan, serta hubungannya dengan tuhan.

\section{Environmental Dimensional}

The Physical Environment merupakan lingkungan fisik di sekitar individu, bangunan, keamanan, kenyamanan, suasana dalam perusahaan.

Culture merupakan budaya yang kita anut atau mewarnai kehidupan kita sehari-hari, terkait dimana kita berada.

Time Dimensional 
Time dimensional terdiri dari trends yang merupakan visi dan misi remaja punk, cycles berupa perilaku dan pandangan tentang visi, shift berupa kejadian yang dapat mengubah arah hidup remaja punk, linear time berupa rencana serta kejadian yang telah dialami, social institutions and social structure berupa organisasi yang diikuti remaja punk, dyads berupa hubungan dengan pasangan, families berupa hubungan dengan keluarga, small groups berupa grup kecil yang diikuti remaja punk, formal organizations berupa organisasi formal yang diikuti, communities berupa hubungan dengan komunitas dan social movements berupa aksi-aksi yang dilakukan oleh remaja punk.

Person dimensional remaja punk yang terdiri dari kondisi biologis yang terdiri dari gambaran fisik, penampilan. Kondisi psikologis yang terdiri dari gambaran emosi, respon terhadap masalah, pola pikir dan cara menghadapi situasi. Kemudian kondisi spiritual yang terdiri dari etika, keyakinan, kepercayaan dan hubungan dengan Tuhan.

Environmental Dimensional remaja punk kondisi lingkungan fisik di sekitar individu dan budaya yang dianut individu.

Time Dimensional remaja punk yang terdiri dari trends yang merupakan visi dan misi remaja punk, cycles berupa perilaku dan pandangan tentang visi, shift berupa kejadian yang dapat mengubah arah hidup remaja punk, linear time berupa rencana serta kejadian yang telah dialami, social institutions and social structure berupa organisasi yang diikuti remaja punk, dyads berupa hubungan dengan pasangan, families berupa hubungan dengan keluarga, small groups berupa grup kecil yang diikuti remaja punk, formal organizations berupa organisasi formal yang diikuti, communities berupa hubungan dengan komunitas dan social movements berupa aksi-aksi yang dilakukan oleh remaja punk.
Punk merupakan subkultur. Subkultur adalah gejala budaya dalam masyarakat industri maju yang umumnya terbentuk berdasarkan usia dan kelas. Secara simbolis diekspresikan dalam bentuk pencipta gaya dan bukan hanya merupakan penentang hegemoni atau jalan keluar suatu ketegangan sosial. Subkultur lebih jauh menjadi bagian dari ruang bagi penganutnya untuk memberikan otonomi dalam suatu tatanan sosial masyarakat industri yang semakin kaku dan kabur.

\section{DAFTAR PUSTAKA}

Budi Wibhawa, Santoso Tri Raharjo \& Meilany Budiarti. 2010. Dasar-Dasar Pekerja Sosial. Bandung: Widya Padjadjaran.

Pickles, Joanna Margaret, 2000. Dari Subkultur ke Budaya Perlawanan : Aspirasi dan Pemikiran Sebagian Kaum Punk/Hardcore dan Skinhead di Yogyakarta dan Bandung. Malang: Universitas Muhammadiyah.

Kauma, Fuad. 1999. Sensasi Remaja di Masa Puber, Dampak Negatif dan Penanggulangannya. Jombang: Kalam Mulia.

Marshall, G. 2005. Skinhead NationTruth about The Skinhead Cult. London: Dunnon.

Nando, 2008. Rebel 35 Band Punk Paling Berpengaruh. Jakarta : Narasi.

Rohman, Arif. 2009. Fenomena Anak Punk: Sisi Lain Mengenai Ruwetnya Permasalahan Anak Jalanan di Indonesia. Warta Demografi.

Santrock. 2007. Remaja, Jilid 1 Edisi Kesebelas. Jakarta: Erlangga

Santrock. 2007. Remaja, Jilid 2 Edisi Kesebelas. Jakarta: Erlangga 